Artikel Penelitian

\title{
Kandungan Gizi Buah Pandan Laut (Pandanus tectorius Park.) pada Tiga Tingkat Kematangan
}

\section{Nutritions Composition of Pandan laut (Pandanus tectorius Park.) Fruit at Three Maturity Level}

Zita Letviany Sarungallo ${ }^{{ }^{*}}$, Cicilia Maria Erna Susanti ${ }^{2}$, Nurhaidah Iriany Sinaga ${ }^{3}$, Diana Nurini Irbayanti ${ }^{4}$, Rossa

Marlen Martha Latumahina ${ }^{1}$

${ }^{1}$ Laboratorium Teknologi Pertanian, Fakultas Teknologi Pertanian, Universitas Papua, Papua Barat

${ }^{2}$ Laboratorium Teknologi Hasil Hutan, Fakultas Kehutanan, Universitas Papua, Papua Barat

${ }^{3}$ Laboratorium Konservasi Sumber Daya Hutan, Fakultas Kehutanan, Universitas Papua, Papua Barat

${ }^{4}$ Laboratorium Agribisnis, Fakultas Pertanian, Universitas Papua, Papua Barat

*Korespondensi dengan penulis (zlsarungallo@yahoo.com)

Artikel ini dikirim pada tanggal 16 Oktober 2017 dan dinyatakan diterima tanggal 28 Februari 2018. Artikel ini juga dipublikasi secara online melalui www.jatp.ift.or.id. Hak cipta dilindungi undang-undang. Dilarang diperbanyak untuk tujuan komersial.

Diproduksi oleh Indonesian Food Technologists $₫(\bigodot 2018$

\section{Abstrak}

Buah pandan laut (Pandanus tectorius Park.) tergolong jenis pandan yang penyebarannya hampir di seluruh daerah Asia hingga ujung timur Asia yakni Daratan-daratan Kepulauan Pasifik, termasuk di Provinsi Papua Barat dengan keragaman yang cukup tinggi. Buah ini berpotensi sebagai bahan pangan namun informasi nutrisinya masih sangat terbatas. Penelitian ini bertujuan untuk menentukan komposisi gizi buah pandan laut pada tiga tingkat kematangan, yang merupakan penelitian dasar sebagai upaya pemanfaatannya untuk ketahanan pangan di wilayah pesisir dan pulau-pulau kecil. Pengamatan dilakukan terhadap komposisi gizi (kadar air, abu, lemak, protein, karbohidrat, serat kasar, total gula dan $\beta$-karoten) buah pada 3 tingkat kematangan (fase buah agak matang, matang dan lewat matang) dari 2 klon buah pandan laut, yang masing-masing berasal dari Pulau Mansinam dan Kawasan Pesisir Pantai Utara Manokwari. Hasil penelitian menunjukkan bahwa daging buah pandan laut memiliki kandungan abu berkisar antara 5,15 dan $6,8 \%$ (bk), kadar lemak berkisar $0,4 \%$ hingga $0,5 \%$ (bk), protein $(2,8-4,3 \%$; bk), karbohidrat (71,6-89,9\%; bk), serat kasar (24,4-27,3\%; bk), dan $\beta$-karoten (11,2-33,2 ppm; bk). Kesimpulannya, kandungan total gula dan $\beta$-karoten buah tersebut cenderung meningkat dengan meningkatnya tingkat kematangan buah. Berdasarkan komposisi nutrisinya yang didominasi oleh karbohidrat, berserat dan mengandung $\beta$-karoten, maka buah pandan laut sangat berpotensi untuk diolah menjadi berbagai produk pangan.

Kata Kunci: Buah pandan laut (Pandanus tectorius), tingkat kematangan, kandungan gizi, dan $\beta$-karoten.

\section{Abstract}

Pandan laut (Pandanus tectorius Park.) fruit is a pandanus species that spread almost throughout Asia to the east of Asia and Pacific Island including in West Papua Province with considerable diversity. This fruit is potential as food but nutritional information is still very limited. This study aims to determine the nutritional composition of pandan laut fruit at three levels of maturity, which is a basic study as an effort to utilize for food security in coastal areas and small islands. Observations were made on the nutritional composition (moisture content, ash, fat, protein, carbohydrate, crude fiber, total sugar and $\beta$-carotene) at 3 levels of maturity (half ripe, ripe and over ripe)) of 2 clones pandan laut fruit each of which comes from Mansinam Island and Northern Coastal area of Manokwari. The results showed that pandan laut flesh has ash content ranged between 5.15 and $6.8 \%$, fat content ranged from 0.4 to $0.5 \%$, protein (2.8-4.3\%), carbohydrates (71.6-89.9\%), crude fiber (24.4-27.3\%), and $\beta$-carotene (11.2-33.2 ppm). As conclusion, the total of sugar and $\beta$-carotene content of these fruits tends to increase as the fruit maturity level increases. Based on the composition of nutrients which are dominated by carbohydrates, crude fiber and contain $\beta$ carotene, the fruit of pandan laut is potential to be processed into various food products.

\section{Keyword: Pandan laut (Pandanus tectorius) fruit, maturity level, nutritionus, and $\beta$-carotene}

\section{Pendahuluan}

Pandanus tectorius atau yang dikenal di beberapa daerah di Indonesia sebagai pandan laut atau pandan tikar tergolong dalam famili Pandanus, yang penyebarannya hampir di seluruh daerah Asia yang memiliki pantai hangat hingga di ujung timur Asia yakni Negara kepulauan Pasifik, termasuk di Provinsi Papua Barat dengan keragaman yang cukup tinggi (Englberger et al., 2003a).

Buah pandan laut berbentuk bulat telur (oval) sampai lonjong, buah matang berwarna kuning sampai orange bahkan sampai merah, dan bersifat lengket dengan rasa manis asam (Thomson et al., 2006).
Dijelaskan pula bahwa tandan buahnya memiliki banyak bagian yang disebut drupa, yang memiliki berat masingmasing sekitar 60-200 gram. Pemanfaatan buah pandan laut sebagai bahan pangan oleh penduduk di Pulau Pasifik dan Mikronesia, dengan cara dikonsumsi segar, atau daging buahnya diekstrak dan dimasak atau diawetkan (Englberger et al., 2003a). Dilaporkan pula bahwa buah pandan laut mengandung zat gizi yang cukup tinggi meliputi protein $2,42-3,66 \%$, lemak 4,46 $4,86 \%$, abu $6,19-7,56 \%$ dan karbohidrat $56,8-63,6 \%$, serta mengandung kalsium (742-864 $\mathrm{mg} / 100 \mathrm{~g})$, besi $(16,9-21,8 \mathrm{mg} / 100 \mathrm{~g})$, dan $\beta$-karoten (108-456 ppm) 
Tabel 1. Kriteria 3 tingkat kematangan buah pandan laut berdasarkan perubahan fisik buah

Perubahan karakter
fisik buah pandan laut

Warna bagian yang

dapat dimakan

Jarak antar drupa

Tingkat kematangan buah

\begin{tabular}{ccc}
\hline Agak Matang & Matang & Lewat matang \\
\hline Kuning muda & Kuning & Kuning tua - oranye
\end{tabular}

Rapat dan keras saat dilepaskan dari empulur.
Membuka atau merekah tapi retakan antar drupa belum jelas, agak mudah terlepas dari empulur.
Makin merekah, antar drupa sudah terlihat jelas retakannya dan sangat mudah terlepas dari empulur.

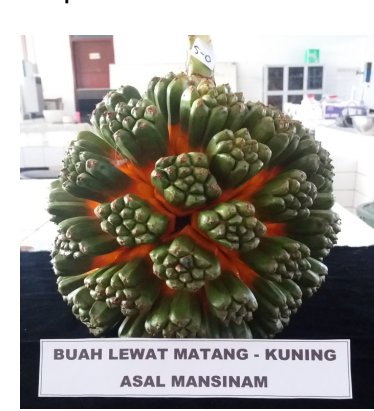

(Sinaga et al., 2011), sehingga berpotensi untuk diolah menjadi berbagai produk pangan.

Perkembangan buah selama proses pematangan sangat mempengaruhi komposisi kimia dan komponen aktif buah, sehingga dapat digunakan dalam penentuan waktu panen yang optimal, untuk mencegah terjadinya penurunan mutu buah sebelum diolah (Sarungallo et al., 2016). Lebih lanjut Herianus et al., (2003) menjelaskan bahwa proses pematangan buah mangga melibatkan serangkaian reaksi biokimia, yang mengakibatkan peningkatan respirasi, produksi etilen, perubahan struktur polisakarida yang menyebabkan pelunakan, degradasi klorofil, pigmen berkembang oleh biosintesis karotenoid, perubahan karbohidrat atau konversi pati menjadi gula, asam organik, lemak, fenolat dan senyawa volatil, sehingga menyebabkan pemasakan buah dengan melembutkan tekstur menjadi kualitas yang dapat diterima. Hertiningsih (2003) melaporkan pula bahwa umur panen biji dan varitas kacang tanah sangat mempengaruhi kadar air, protein, lemak dan karbohidrat biji. Sementara itu, Sarungallo et al. (2016) melaporkan bahwa kadar lemak dan komponen aktif (karoten dan tokoferol) buah merah (Pandanus conoideus) meningkat seiring dengan peningkatan kematangan.

Buah pandan laut sangat berpotensi sebagai bahan pangan namun belum dmanfaatkan secara optimal, karena minimnya informasi perkembangan nutrisinya selama pengembangan kematangan buahnya. Penelitian ini bertujuan untuk menentukan komposisi gizi buah pandan laut pada tiga tingkat kematangan, yang merupakan penelitian dasar sebagai upaya pemanfaatannya untuk ketahanan pangan di daerah pesisir pantai.

\section{Materi dan Metode \\ Materi}

Bahan baku utama dalam penelitian ini adalah buah pandan laut (Pandanus tectorius) yang berasal dari 2 lokasi di Kabupaten Manokwari yaitu Pulau Mansinam dan Pantai Utara (kampung Pami) kabupaten Manokwari Provinsi Papua Barat, pada 3 tingkat kematangan buah dengan kriteria seperti yang disajikan pada Tabel 1, sedangkan bahan-bahan kimia untuk analisis komposisi proksimat, serta dan kadar $\beta$-karoten daging buah pandan laut dengan kualitas Pro Analysis. Peralatan yang digunakan antara lain timbangan analitik, hot plate, water bath, pendingin, alat sokhlet, alat dekstruksi, tanur, alat titrasi, High Performance Liquid Chromatography(HPLC Agilent seri 1100) dan peralatan gelas lainnya.

\section{Metode}

Metode yang digunakan dalam penelitian ini adalah observasi di lapangan dan analisis kimia di laboratorium. Penelitian terdiri atas 2 tahap penelitian yaitu (1) karakterisasi fisik buah, yaitu warna, ukuran berat dan panjang buah, serta bagian buah yang dapat dimakan, (2) analisis kandungan proksimat daging buah, serat kasar dan $\beta$-karoten.

Analisis komposisi kimia dari buah setiap fase kematangan buah meliputi kadar air (metode oven), kadar abu (metode tanur), kadar lemak (ekstraksi soxhlet), dan kadar protein (kjeldahl mikro) (AOAC, 2005), sedangkan karbohidrat ditentukan berdasarkan by different, serta kadar serat (metode gravimetri) dan kadar $\beta$-karoten menggunakan HPLC Agilent seri 1100 dengan kolom Thermo C18, dan fase gerak metanol:etil asetat:asetonitril (23:9:68) dengan laju aliran $1 \mathrm{ml} / \mathrm{menit}$. $\beta$-karoten dideteksi dan diukur pada panjang gelombang $450 \mathrm{~nm}$ (AOAC, 2005).

\section{Analisis Data}

Semua data kuantitatif yang diperolah dianalisis secara statistik dengan menggunakan analisis ragam (ANOVA), apabila perlakuan berpengaruh nyata dilanjutkan dengan Uji DMRT (Duncans Multiple Range Test) pada taraf kepercayaan 5\%, menggunakan Program SPSS (Statistical Productand Service Solution), versi 17,0 . 
Tabel 2. Kadar proksimat buah pandan dari 2 lokasi berbeda pada 3 tingkat kematangan buah

\begin{tabular}{clccccccc}
\hline $\begin{array}{c}\text { Asal buah } \\
\text { pandan laut }\end{array}$ & $\begin{array}{c}\text { Tingkat } \\
\text { Kematangan } \\
\text { Buah }\end{array}$ & $\begin{array}{c}\text { Air } \\
(\% \mathrm{bb})\end{array}$ & $\begin{array}{c}\text { Abu } \\
(\% \mathrm{bk})\end{array}$ & $\begin{array}{c}\text { Karbohidrat } \\
(\% \mathrm{bk})\end{array}$ & $\begin{array}{c}\text { Protein } \\
(\% \mathrm{bk})\end{array}$ & $\begin{array}{c}\text { Lemak } \\
(\% \mathrm{bk})\end{array}$ & $\begin{array}{c}\text { Serat } \\
\text { kasar } \\
(\% \mathrm{bk})\end{array}$ & $\begin{array}{c}\text { Total } \\
\text { Gula } \\
(\% \mathrm{bk})\end{array}$ \\
\hline Pulau & Agak matang & $74,21^{\mathrm{c}}$ & $5,45^{\mathrm{b}}$ & $89,88^{\mathrm{b}}$ & $4,30^{\mathrm{b}}$ & $0,36^{\mathrm{a}}$ & $25,95^{\mathrm{b}}$ & $31,6^{\mathrm{c}}$ \\
Mansinam & Matang & $76,93^{\mathrm{a}}$ & $6,79^{\mathrm{a}}$ & $87,96^{\mathrm{c}}$ & $4,82^{\mathrm{a}}$ & $0,44^{\mathrm{a}}$ & $26,56^{\mathrm{a}}$ & $44,8^{\mathrm{a}}$ \\
& Lewat matang & $76,64^{\mathrm{b}}$ & $5,09^{\mathrm{c}}$ & $90,39^{\mathrm{a}}$ & $4,10^{\mathrm{b}}$ & $0,42^{\mathrm{a}}$ & $24,38^{\mathrm{c}}$ & $34,4^{\mathrm{b}}$ \\
\cline { 2 - 10 } Pantai Utara & Agak matang & $78,68^{\mathrm{b}}$ & $5,86^{\mathrm{ab}}$ & $89,25^{\mathrm{b}}$ & $4,41^{\mathrm{a}}$ & $0,49^{\mathrm{a}}$ & $27,32^{\mathrm{a}}$ & $27,5^{\mathrm{c}}$ \\
& Matang & $79,53^{\mathrm{a}}$ & $5,93^{\mathrm{a}}$ & $90,20^{\mathrm{a}}$ & $3,49^{\mathrm{b}}$ & $0,39^{\mathrm{b}}$ & $26,59^{\mathrm{b}}$ & $47,1^{\mathrm{a}}$ \\
& Lewat matang & $78,04^{\mathrm{c}}$ & $5,51^{\mathrm{b}}$ & $90,78^{\mathrm{a}}$ & $3,30^{\mathrm{c}}$ & $0,41^{\mathrm{ab}}$ & $24,73^{\mathrm{c}}$ & $41,4^{\mathrm{b}}$ \\
\hline
\end{tabular}

Keterangan:

Huruf yang berbeda dibelakang angka menunjukkan beda nyata $(\mathrm{P}<0,05)$ pada setiap asal buah; bb artinya berat basah; bk artinya berat kering.

\section{Hasil dan Pembahasan}

Hasil analisis proksimat daging buah pandan laut dari 2 lokasi di Manokwari yang meliputi kadar air, abu, karbohidrat, protein, maupun lemak pada setiap ke-3 tingkat kematangan buah yaitu agak matang, matang, dan lewat matang menunjukkan adanya perubahan (Tabel 2).

\section{Kadar air}

Kadar air buah dapat berbeda satu sama lain dipengaruhi ketersediaan air dalam jaringan pada waktu panen sehingga sangat mempengaruhi tekstur bahan (Muchtadi et al., 2010). Kadar air buah pandan laut dari setiap tingkat kematangan berkisar antara 74,21-79,53\% (Tabel 2). Hasil sidik ragam memperlihatkan bahwa tingkat kematangan buah berpengaruh nyata terhadap kadar air pada setiap jenis buah pandan laut. Hasil uji lanjutan dengan Uji Wilayah Berganda Duncan $(\mathrm{P}<0,05)$ memperlihatkan bahwa penurunan kadar air pada setiap tingkat kematangan berbeda nyata pada setiap jenis buah, dimana terdapat cenderung meningkat sampai fase matang dan mengalami penurunan pada fase lewat matang. Fenomena yang sama juga dilaporkan terjadi pada buah merah atau Pandanus conoideus (Sarungallo et al., 2016). Lebih lanjut Chamma et al. (1990) menjelaskan bahwa penurunan kadar air biji kacang buncis mulai umur 67 sampai 101 hari, dari $60 \%$ menjadi $19 \%$, disebabkan karena pada proses fotosintesis, air dan karbondioksida diubah menjadi berat (bahan) kering biji maupun bagian tanaman lainnya.

Data pada Tabel 2 juga memperlihatkan bahwa kadar air buah asal Pantai Utara lebih tinggi dibandingkan asal Pulau Mansinam. Perbedaan kadar air tersebut berkaitan dengan karakteristik genetik setiap jenis/klon yang dapat mempengaruhi perkembangan fisiologis buah. Disamping itu kadar air buah pandan relatif tinggi (di atas 60\%) sehingga dapat mempercepat kerusakan kimia, fisik dan mikrobiologi setelah dipanen terlebih pada kondisi cuaca panas dan mengalami kerusakan mekanis akibat benturan. Oleh karena itu untuk meminimalisasi kerusakan buah saat panen diperlukan cara panen dan menggunakan kemasan yang tepat untuk transportasi dari lokasi penanaman ke tempat pengolahan.

\section{Kadar abu}

Kadar abu menyatakan jumlah kandungan unsur mineral pada buah pandan laut yang berkisar 5,09-
$6,79 \%$ (Tabel 2). Hasil sidik ragam memperlihatkan bahwa tingkat kematangan berpengaruh nyata terhadap kadar abu buah pandan laut. Hasil uji lanjutan $(P<0,05)$ menunjukkan bahwa tingkat kematangan buah berpengaruh nyata terhadap kadar abu buah pandan laut; dimana kadar abu buah asal Pulau Mansinam meningkat pada fase matang dan menurun pada fase lewat matang. Sementara itu, kadar abu buah asal Pantai Utara antara fase agak matang dan matang tidak berbeda nyata, namun cenderung menurun secara nyata pada fase lewat matang. Sarungallo et al. (2016) melaporkan pula bahwa kadar abu buah merah serta kadar kalsium dan fosfor dari 3 klon juga mengalami penurunan sampai pada fase lewat matang. Penurunan kadar abu pada buah pandan laut ini diduga karena mineral ikut berperan dalam proses metabolism pertumbuhan dan perkembangan buah pada tanaman. Ditambahkan pula bahwa kadar abu buah pandan laut ini lebih tinggi dibandingkan dengan kadar abu buah merah yang berkisar 3,0-6,2\% (Sarungallo et al., 2016). Menurut Harris (1989), kadar mineral buah lebih dipengaruhi oleh komposisi tanah tempat tumbuhnya.

\section{Kadar Karbohidrat}

Kisaran kadar karbohidrat buah pandan laut pada berbagai tingkat kematangan bervariasi dari 87,96$90,20 \%$ (Tabel 2). Hasil sidik ragam menunjukkan bahwa tingkat kematangan buah berpengaruh nyata terhadap kadar karbohidratnya. Sedangkan hasil uji lanjutan $(P<0,05)$ memperlihatkan bahwa tingkat kematangan memberikan perbedaan nyata kadar karbohidrat buah pandan laut. Kadar karbohidrat buah asal Pulau Mansinam cenderung menurun pada fase matang dan meningkat pada fase lewat matang. Sementara buah asal Pantai Utara cenderung menurun pada fase matang kemudian meningkat pada fase lewat matang.

Sarungallo et al. (2016) melaporkan pula bahwa kadar karbohidrat buah merah dari 3 klon bervariasi pada beberapa tingkat kematangan, yang kadarnya cenderung menurun sampai pada fase lewat matang. Lebih lanjut dijelaskan bahwa pada umumnya karbohidrat pada waktu buah masih muda atau masa pertumbuhan dan perkembangan akan mencapai kadar maksimum selama pematangan buah, karena terjadinya proses konversi pati menjadi gula pereduksi selama proses pematangan sehingga menimbulkan rasa manis pada buah (Winarno dan Aman, 1981), yang berkaitan 
dengan karakteristik proses biokimia dan fisiologis komponen kimia yang spesifik pada setiap kultivar dipengaruhi genetiknya.

\section{Kadar protein}

Protein merupakan salah satu komponen gizi yang penting untuk disintesis tanaman. Kadar protein buah pandan laut pada berbagai tingkat kematangan bervariasi dari 3,30-4,82\% (Tabel 2), dimana terdapat kecenderungan kadar protein buah pandan laut meningkat pada fase matang, namun menurun kembali pada fase lewat matang. Hasil sidik ragam memperlihatkan bahwa tingkat kematangan buah berpengaruh nyata terhadap kadar protein pada setiap jenis buah pandan laut. Hasil uji lanjutan $(P>0,05)$ menunjukkan bahwa kadar protein berbeda nyata antar setiap tingkat kematangan buah, dimana buah asal Pulau Mansinam cenderung meningkat sampai fase matang kemudian menurun kembali pada fase lewat matang, sementara pada buah asal Pantai Utara kandungan proteinnya cenderung menurun sampai pada fase lewat matang. Fenomena perubahan protein buah padan laut ini tidak berbeda dengan buah merah dari 3 klon, yang kadar proteinnya cenderung menurun dengan meningkatnya tingkat kematangan buah pada kisaran 1,86 sampai 4,3\% (Sarungallo et al., 2016).

Secara fisiologis protein pada buah sebagai bahan struktural dari membran sel dan enzim dalam katalis reaksi-reaksi anabolik dan katabolik (Muchtadi et al., 2010). Sehingga diduga penurunan kadar protein buah merah karena digunakan dalam proses pertumbuhan sel oleh aktivits enzim menyebabkan perubahan komponen lain dalam jaringan buah. Kadar protein buah pandan laut tergolong rendah sehingga konsumsinya tidak ditujukan untuk memberikan kontribusi protein.

\section{Kadar lemak}

Kadar lemak buah pandan laut selama perkembangan kematangannya tergolong rendah dengan kisaran 0,36-0,49\% (Tabel 2). Hasil sidik ragam menunjukkan bahwa tingkat kematangan buah berpengaruh nyata terhadap kadar lemak buah pandan. Sementara itu, hasil uji lanjut dengan Uji Wilayah Berganda Duncan $(P<0,05)$ menunjukkan bahwa kadar lemak buah asal Pulau Mansinam tidak berbeda nyata antara 3 tingkat kematangan; sedangkan buah asal Pulau Mansinam menunjukkan perbedaan nyata, yang kadarnya cenderung menurun sampai pada fase lewat matang.

Kecenderungan ini sama dengan laporan Sarungallo et al. (2016) bahwa perubahan kadar lemak pada setiap fase kematangan buah merah setiap klon bervariasi, ada yang meningkat sampai fase matang dan menurun kembali pada fase lewat matang; namun beberapa klon menunjukkan peningkatan kadar lemak sampai pada fase lewat matang. Demikian halnya dengan Hertiningsih (2003) yang menyatakan bahwa kandungan lemak kacang tanah meningkat sampai maksimum dengan bertambahnya umur biji, namun pada umur 61 hari setelah berbunga mengalami penurunan. Penurunan kandungan lemak ini diduga karena adanya perombakan cadangan makanan pada kotiledon padahal transfer dan pembentukannya sudah dihentikan.

\section{Kadar Serat Kasar}

Kadar serat kasar buah pandan laut pada berbagai tingkat kematangan bervariasi dari 24,3827,32\% (Tabel 2). Hasil sidik ragam menunjukkan bahwa tingkat kematangan buah berpengaruh nyata terhadap kadar serat kasar buah pandan. Sedangkan hasil uji lanjutan $(P<0,05)$ memperlihatkan bahwa kadar serat kasar buah pandan laut berbeda nyata antar setiap tingkat kematangan buah. Secara fisik terlihat bahwa daging buah pandan laut merupakan serat-serat yang semakin matang semakin berair (kadar air meningkat sampe fase matang kemudian menurun pada fase lewat matang, Tabel 2). Kadar serat kasar buah pandan laut asal Pulau Mansinam cenderung meningkat sampai fase matang, kemudian menurut pada fase lewat matang; Sedangkan kadar serat kasar buah asal Pantai Utara terus meningkat sampai pada fase lewat matang.

Penurunan kadar serat kasar selama proses pematangan buah sangat terkait dengan terjadinya proses perubahan tekstur buah. Selama proses pematangan buah terjadi proses pelunakan tekstur buah karena adanya pektin yang tidak larut (protopektin) yang berkurang jumlahnya dan berubah menjadi pektin yang dapat larut. Disamping itu pelunakan dinding sel buah juga disebabkan oleh perubahan turgor sel yang menyebabkan hilangnya sifat getas dan kesegaran jaringan buah. Sifat tekstur tersebutjuga dipengaruhi juga oleh tingkat kemasakan, sifat yang diwariskan, kondisi kultural dan kelembabannya (Suhardi et al., 1988). Dijelaskan pula bahwa buah yang masih muda, hubungan antara sel yang satu dengan yang lain masih kuat karena pektin yang bertindak sebagai perekat masih baik. Bila buah menjadi tua atau matang, pektin yang semula tidak larut ini terhidrolisa menjadi pektin yang larut. Akibatnya daya rekat menjadi berkurang sehingga buah menjadi lunak (Eskin et al., 1971)

Data pada Tabel 2 juga memperlihatkan bahwa pada fase lewat matang kadar air cenderung berkurang sehingga kadar serat meningkat. Kadar serat buah pandan laut ini cukup tinggi sehingga dalam proses pengolahan buah pandan laut menjadi berbagai produk pangan seperti dodol, sirup dan selai, maka dalam tahapan preparasinya diawali dengan pemarutan daging buah yang diikuti dengan tahap penyaringan untuk memisahkan daging buah yang halus dengan serat kasarnya.

\section{Kadar Total Gula}

Kadar total gula buah pandan laut bervariasi pada 3 tingkat kematangan yang bervariasi dari $26,5-44,8 \%$ (Tabel 2). Hasil sidik ragam menunjukkan bahwa tingkat kematangan buah berpengaruh nyata terhadap kadar total gula buah pandan laut. Sementara itu, hasil uji lanjut $(P<0,05)$ menunjukan bahwa kadar total gula buah pandan laut berbeda nyata antara 3 tingkat kematangan; dimana terdapat kecenderungan mengalami 
peningkatan pada fase matang kemudian menurun sampai pada fase lewat matang. Lebih lanjut Kansci et al. (2003) juga melaporkan bahwa daging buah matang dari empat varietas mangga mengandung gula yang lebih mudah larut daripada yang muda. Selain itu, tidak ada pati pada mangga Keitt yang matang, yang menunjukkan total transformasi menjadi gula larut saat pemasakan. Indikasi ini terkait dengan karakteristik komponen biokimia dan fisiologis pengaruh genetik senyawa kimia spesifik pada masing-masing kloning.

Peningkatan kadar gula ini terjadi seiring dengan meningkatnya pematangan buah (Pantastico, 1993). Lebih lanjut Winarno dan Aman (1981) menjelaskan bahwa pada waktu buah masih muda atau masa pertumbuhan dan perkembangan dan akan maksimum selama pematangan buah, hal ini terkait dengan proses konversi pati menjadi gula pereduksi selama proses pematangan sehingga menimbulkan rasa manis pada buah. Pada umumnya buah mengandung gula dalam bentuk monosakarida (fruktosa dan glukosa) dan disakarida (sukrosa).

Tabel 3. Kadar $\beta$-karoten buah pandan laut pada 3 tingkat kematangan buah

\begin{tabular}{lcc}
\hline $\begin{array}{l}\text { Asal buah } \\
\text { pandan laut }\end{array}$ & $\begin{array}{c}\text { Tingkat Kematangan } \\
\text { Buah }\end{array}$ & $\begin{array}{c}\beta \text {-karoten } \\
(\mathrm{ppm}, \mathrm{bk})\end{array}$ \\
\hline Pulau Mansinam & Agak matang & $26,45^{\mathrm{c}}$ \\
& Matang & $29,52^{\mathrm{b}}$ \\
& Lewat matang & $36,72^{\mathrm{a}}$ \\
Pantai Utara & Agak matang & $12,76^{\mathrm{b}}$ \\
& Matang & $14,37^{\mathrm{a}}$ \\
& Lewat matang & $13,28^{\mathrm{b}}$ \\
\hline
\end{tabular}

Keterangan: huruf yang berbeda dibelakang angka menunjukkan beda nyata $(P<0,05)$ pada setiap asal buah

\section{Kadar $\beta$-karoten}

Warna alami buah pandan laut yang matang pada bagian yang dapat dimakan berwarna kuning sampai oranye, yang terutama disebabkan oleh kandungan karotenoidnya, dimana semakin matang warna kuningnya semakin tua (oranye). Kadar $\beta$-karoten dari 2 klon buah pandan laut selama perkembangan tingkat kematangannya berkisar antara 12,76-36,72 ppm (bk) (Tabel 3). Data yang diperoleh dalam kajian ini setara dengan laporan Englberger et al. (2003b) bahwa kadar $\beta$-karoten buah pandan laut asal Micronesia bervariasi tergantung dari warna daging buahnya, yaitu buah berwarna oranye berkisar 21,1-39,3 ppm, kuning 0,87 ppm dan agak kuning 0,19 ppm.

Hasil sidik ragam menunjukkan bahwa tingkat kematangan buah sangat berpengaruh nyata terhadap kadar $\beta$-karoten buah pandan laut. Hasil uji lanjutan dengan Uji Wilayah Berganda Duncan $(P<0,05)$ menunjukkan bahwa kadar $\beta$-karoten maksimal dicapai pada fase lewat matang berbeda nyata dengan tingkat kematangan lain.

Umumnya klorofil pada buah akan terdegradasi selama proses pematangan menghasilkan sejumlah besar karotenoid (Wilska-Jeszka, 2002). Pada buah pandan laut, sejumlah besar karotenoid telah terbentuk sejak buah agak matang sehingga merupakan sumber karoten yang baik. Dengan demikian tingkat kematangan merupakan salah satu faktor penting yang mempengaruhi kadar karotenoid, yang terbentuk pada kromoplas dan kloroplas sel buah pandan laut. Sarungallo et al., (2016) juga melaporkan bahwa kadar total karotenoid buah merah cenderung meningkat selama proses pematangan buah dan maksimal dicapai pada fase lewat matang. Sedangkan Kato et al., (2004) menyatakan bahwa akumulasi karotenoid terbanyak pada beberapa kultivar jeruk yang berada dalam masa akhir pematangan.

Data pada Tabel 3 juga memperlihatkan bahwa kadar $\beta$-karoten buah pandan laut asal Pulau Mansinam relatif lebih tinggi dari buah asal Pantai Utara, yang sejalan dengan kadar lemaknya. Menurut Harris (1989) kemampuan enzim tanaman dalam mensintesis komponen vitamin dikendalikan secara genetik, namun kadarnya dalam jaringan tanaman dipengaruhi juga oleh faktor lingkungan seperti cahaya, panas, air, dan tanah. Buah pandan laut yang digunakan pada penelitian ini berasal dari 2 daerah tempat tumbuh yang berbeda yaitu Pantai Utara kabupaten Manokwari dan Pulau Mansinam, sehingga perbedaan kadar $\beta$-karoten dari ke2 jenis buah tersebut dapat dipengaruhi oleh tempat budidaya dan genetik.

\section{Kesimpulan}

Kandungan total gula dan $\beta$-karoten buah pandan laut cenderung meningkat dengan meningkatnya tingkat kematangan buah. Berdasarkan komposisi nutrisinya yang didominasi oleh karbohidrat, berserat dan mengandung $\beta$-karoten, maka buah pandan laut sangat berpotensi untuk diolah menjadi berbagai produk pangan.

\section{Ucapan Terima Kasih}

Peneliti mengucapkan terima kasih kepada Kemenristek-Dikti melalui Direktorat Riset dan Pengabdian Pada Masyarakat (PPM) sesuai dengan Surat Perjanjian Pelaksanaan Program Penelitian No. 162/SP2H/LT/DRPM/III/2016 tanggal 10 Maret 2016.

\section{Daftar Pustaka}

AOAC (Association of Analytical Chemist). 2005. Official Methods of Analysis of AOAC International. $16^{\text {th }}$ edition. AOAC Inc., Wahington DC., USA.

Chamma, H.M., Marcos-Filho, J., Crocomo, O.J. 1990. Maturation of seeds of 'Aroana' beans (Phaseolus vulgaris L.) and its influence on the storage pontential. Seed Science and Technology 18(2):371-382.

Englberger, L., Fitzgerald, M.H., Marks, G.C. 2003a. Pacific pandanus fruit: an ethnographic approach to understanding an overlooked source of provitamin A carotenoids. Asia Pacific Journal of Clinical Nutrition 12(1):38-44. PMIID 12737009.

Englberger, L., Aalbersberg, W., Fitzgerald, M.H., Marks G.C., Chand, K. 2003b. Provitamin A carotenoid content of different cultivars of edible pandanus fruit. Journal of Food Composition and Analysis 16(2): 237-247. DOI:10.1016/S0889-1575(02) 00169-2. 
Eskin, N.A.M., Henderson, H.M., Townseed, R.L. 1971. Biochemistry of Foods. Academic Press, New York.

Harris, R. H. 1998. Pengaruh budidaya pertanian terhadap susunan bahan pangan. Dalam: Harris, R.S., Karmas, E. Evaluasi gizi pada pengolahan bahan pangan. Penerjemah: Achmadi, S. Penerbit ITB, Bandung.

Herianus, J.D., Singh, L.Z., Tan, S.C.. 2003. Aroma volatiles production during fruit ripening of Kensington Pride mango. Postharvest Biology ang Technology 27(3):323-336. DOI: 10.1016/S09255214(02)00117-5.

Hertiningsih, A. 2003. Pengaruh waktu panen terhadap kandungan gizi dari 2 varietas biji kacang (Arachis hypogaea L.). Biota 8(2): 89-93.

Kansci, G., Koubala, B.B. and Lape, I. M. 2003. Effect of ripening on the composition and the suitability for jam processing of different varieties of mango (Mangifera indica). African Journal of Biotechnology 2(9):301-306. DOI: 10.5897/AJB 2003.000-1061.

Kato, M., Ikoma, Y., Matsumoto, H., Sugiura, M., Hyodo, H., Yano, M. 2004. Accumulation of carotenoids and expression of carotenoid biosynthetic genes during maturation in citrus fruit. Plant Physiology 134:824-837. DOI: 10.1104/pp.103.031104.

Muchtadi, T.R., Sugiyono, R., Fitryono, A. 2010. IImu Pengetahuan Bahan Pangan. Alfabeta, Bandung.

Pantastico, E.R. B. 1993. Postharvest physiology, handling and utilization of tropical and subtropical fruit and vegetables. The AVI Publishing Company Inc., Westport, Connecticut.

Sarungallo, Z.L., Murtiningrum, Santoso, B., Roreng, M.K., Latumahina, R.M.M. 2016. Nutrient content of three clones of red fruit (Pandanus conoideus) during the maturity development. International Food Research Journal 23(3):1217-1225.

Sinaga, N.I., Susanti, C.M.E., Sarungallo, Z.L., Kaber, Y. 2011. Pengentasan kemiskinan dan ketahanan pangan melalui budidaya Pandanus tectorius Park., di kawasan TN Teluk Cenderawasih, Kabupaten Teluk Wondama. Laporan Penelitian. Universitas Papua, Manokwari.

Suhardi, Tranggono, Murdjati, Sudarmanto. 1990. Fisiologi dan Teknologi Pasca Panen. Pusat Antar Universitas Pangan dan Gizi, Universitas Gajah Mada, Yogyakarta.

Thomson, L.A.J., Englberger, L., Guarino, L. Thaman, R.R., Elevitch, C.R. 2006. Pandanus tectorius (Pandanus). Dalam: Elevitch, C.R. Traditional trees of Pasific island: their culture, environment and use. Permanent Agriculture Resources, Holuala, Hawai.

Wilska-Jeszka, J. 2002. Food colorants. Dalam: Sikorski, Z.E. Chemical and functional properties of food components. Second Edition, CRC Press, New York.

Winarno, F.G., Aman, W. 1981. Fisiologi Lepas Panen. Sastra Budaya, Jakarta. 